\title{
PREDIKSI ZONA JENUH AIRTANAH PADA BATUAN DI AREAL PILOT PLANT UNDERGROUND COAL GASIFICATION, MUSI BANYUASIN, SUMATERA SELATAN
}

\author{
Prediction of Groundwater Saturated Zone on the Rock at the Area \\ of UCG Pilot Plant, Musi Banyuasin, South Sumatera
}

\author{
EKO PUJIANTO dan AGUS NUGROHO \\ Puslitbang Teknologi Mineral dan Batubara \\ Jalan Jenderal Sudirman 623 Bandung 40211 \\ Telp. (022) 6030483, Fax. (022) 6003373 \\ e-mail: eko@tekmira.esm.go.id
}

\begin{abstract}
ABSTRAK
Tujuan penyelidikan geofisika ini adalah memprediksi kejenuhan airtanah pada batuan di areal rencana penelitian pilot plant Underground Coal Gasification berdasarkan metode tahanan jenis. Kejenuhan tersebut diinterpretasikan berdasarkan distribusi tahanan jenis $(\rho)$ batuan di bawah permukaan tanah. Data kejenuhan airtanah pada batuan sangat diperlukan dalam operasional gasifikasi batubara bawah tanah, terutama yang berkaitan dengan proses pembakaran lapisan batubara dan gasifikasinya. Dari hasil pemrosesan data dapat diinterpretasikan bahwa hampir seluruh batuan di bawah permukaan di area rencana penelitian memperlihatkan kondisi jenuh dengan airtanah sampai kedalaman 300 meter, yang ditandai dengan nilai $\rho<100 \Omega m$. Kondisi ini merupakan hal yang memerlukan perhatian serius,terutama pada proses pembakaran dan gasifikasi yang lapisan batubaranya terletak di kedalaman 250-300 meter dari permukaan. Nilai $\rho>100 \Omega \mathrm{m}$ hanya dijumpai pada lintasan tertentu dan pada kedalaman relatif dangkal. Oleh karena itu, sangat disarankan melakukan uji pompa untuk mengetahui potensi akuifer secara kuantitatif. Penyelidikan ini memberikan peringatan dini kemungkinan adanya zona jenuh airtanah yang akan berpengaruh pada proses gasifikasi.
\end{abstract}

Kata kunci: geolistrik, tahanan jenis, kejenuhan airtanah pada batuan, pembakaran, gasifikasi lapisan batubara.

\begin{abstract}
The purpose of this geophysical study is to predict the groundwater saturation of rocks in the area of research plans for Underground Coal Gasification pilot plant with geoelectric resistivity method. The saturation is interpreted by the distribution of resistivity $(\rho)$ rocks in the subsurface of the area. Data of groundwater saturation in the rock are very important for the gasification operations, primarily related to the process of combustion and gasification of the coal seam. From the results of data processing, it can be interpreted that almost all the rock layers below the surface in the area of research plans are saturated with groundwater to a depth of 300 meters, which was characterized by the value of $\rho<100 \Omega \mathrm{m}$. This condition requires serious attention, especially in the combustion and gasification process of the coal seam at the depth of 250-300 meters from the surface. Value of $\rho>100 \Omega m$ is only found in a certain section and at relatively shallow depths. Therefore, it is strongly suggested to conduct a pumping test to determine the potential of aquifer quantitatively. This investigation provides early warning of possible groundwater saturated zone that will affect the process of gasification.
\end{abstract}

Keywords: geoelectric resistivity, groundwater saturation in the rock, combustion and gasification of coal seam. 


\section{PENDAHULUAN}

Sumber daya batubara di Indonesia diperkirakan sekitar 161 miliar ton dengan cadangan sebesar 28,17 miliar ton (Pusat Sumber Daya Geologi, 2012). Sekitar 120 miliar ton dari sumber daya tersebut merupakan sumber daya untuk tambang terbuka dan sisanya sekitar 41 miliar ton merupakan sumber daya tambang bawah tanah. Potensi tersebut akan lebih besar lagi bila dihitung sampai kedalaman $1.000 \mathrm{~m}$ di bawah permukaan tanah. Meskipun demikian, pemanfaatan batubara sebagai sumber energi di dalam negeri belum optimal, karena masih bertumpu pada energi minyak dan gas bumi (migas). Namun disadari bahwa peran migas akan makin berkurang, seiring dengan semakin menipisnya cadangan, sementara sumber daya baru belum ditemukan (Santoso, 2015; Santoso, Yunianto dan Zulfahmi, 2015).

Sebagai alternatif pemecahan persoalan kontinuitas sumber energi dalam negeri, pemanfaatan teknologi underground coal gasification (UCG) di Indonesia dipandang layak untuk dikembangkan. Berdasarkan perhitungan awal menggunakan data Indonesian Coalbed Methane (Advanced Resources International, 2003), jumlah sumber daya batubara untuk UCG di Indonesia adalah sebesar 796 miliar ton atau ekuivalen dengan potensi energi 3.309 tcf (trillion cubic feet) setara gas alam atau 39.372 tcf setara gas bakar. Sementara itu, sumber daya gas bumi hanya 150 tcf dan coal bed methane (CBM) 453 tcf. Mempertimbangkan potensi gas dari UCG tersebut, maka penelitian UCG perlu dilakukan di Indonesia.

Teknologi UCG memang memiliki beberapa keunggulan dibandingkan CBM (Bayrak, 2015), namun karena proses ini dijalankan di bawah tanah, maka sangat diperlukan dukungan yang kuat pada data eksplorasi berupa data geologi, geofisika, geoteknik, hidrogeologi, karakteristik batubara dan batuan serta data lingkungan.

Ada tiga metode UCG yang dikenal dan dikembangkan di beberapa negara, yaitu UCG dalam tambang, tekanan tinggi dan pengeboran berarah. Meskipun demikian, apapun metode yang digunakan, tingkat kesuksesannya sangat bergantung pada kelengkapan data dukung sebelum memulai pengoperasian UCG.

Tujuan penelitian ini adalah untuk memprediksi kejenuhan airtanah dalam batuan di areal rencana penelitian pilot plant UCG menggunakan metode tahanan jenis geolistrik. Dalam hal ini, kejenuhan airtanah pada batuan diinterpretasikan berdasarkan distribusi tahanan jenis ( $\rho$ ) batuan di bawah permukaan tanah di areal tersebut (Rustadi, 2008; Yulianto dan Widodo, 2008). Data kejenuhan airtanah pada batuan sangat diperlukan dalam pengoperasian UCG, terutama yang berkaitan dengan proses pembakaran lapisan batubara dan gasifikasi. Penyelidikan ini terbatas mengenai prediksi kejenuhan airtanah pada batuan untuk mengetahui potensi akuifer secara kuantitatif dan untuk menunjang kegiatan tersebut harus dilakukan uji pompa (pumping test).

Lokasi penyelidikan geolistrik, secara geografis terletak di $2^{\circ} 35^{\prime} 00,05^{\prime \prime}-2^{\circ} 33^{\prime} 45,38^{\prime \prime}$ LS dan $103^{\circ} 22^{\prime} 10,12^{\prime \prime}-103^{\circ} 22^{\prime} 55,16^{\prime \prime}$ BT; sedangkan secara administratif daerah tersebut berada di Desa Macang Sakti, Kecamatan Sanga Desa, Kabupaten Musi Banyuasin, Provinsi Sumatera Selatan (Gambar 1). Lokasi kegiatan ini berada dalam wilayah izin usaha pertambangan (IUP) PT. Astaka Dodol, sebuah perusahaan Perjanjian Karya Pengusahaan Pertambangan Batubara (PKP2B) di wilayah tersebut.

\section{METODE}

Penggunaan metode geolistrik tahanan jenis untuk memprediksi kejenuhan airtanah pada batuan adalah berdasarkan beberapa penelitian yang pernah dilakukan sebelumnya, yang kesimpulannya menyebutkan bahwa airtanah mempunyai kontribusi signifikan terhadap besarnya konduktivitas listrik (daya hantar listrik) suatu batuan (Zubaidah dan Kanata, 2008) dan metode geolistrik tahanan jenis dapat digunakan untuk menentukan potensi airtanah berdasarkan distribusi tahanan jenisnya (Bahar, 2012; Pujianto, 2014). Karena kandungan airtanah berpengaruh pada nilai konduktivitas listrik, maka dengan sendirinya akan berpengaruh pada tahanan jenis ( $\rho$ ) batuan dan dengan logika yang sama apabila diketahui distribusi tahanan jenis pada batuan, maka dapat diprediksi kandungan atau kejenuhan airtanah pada batuan tersebut. 


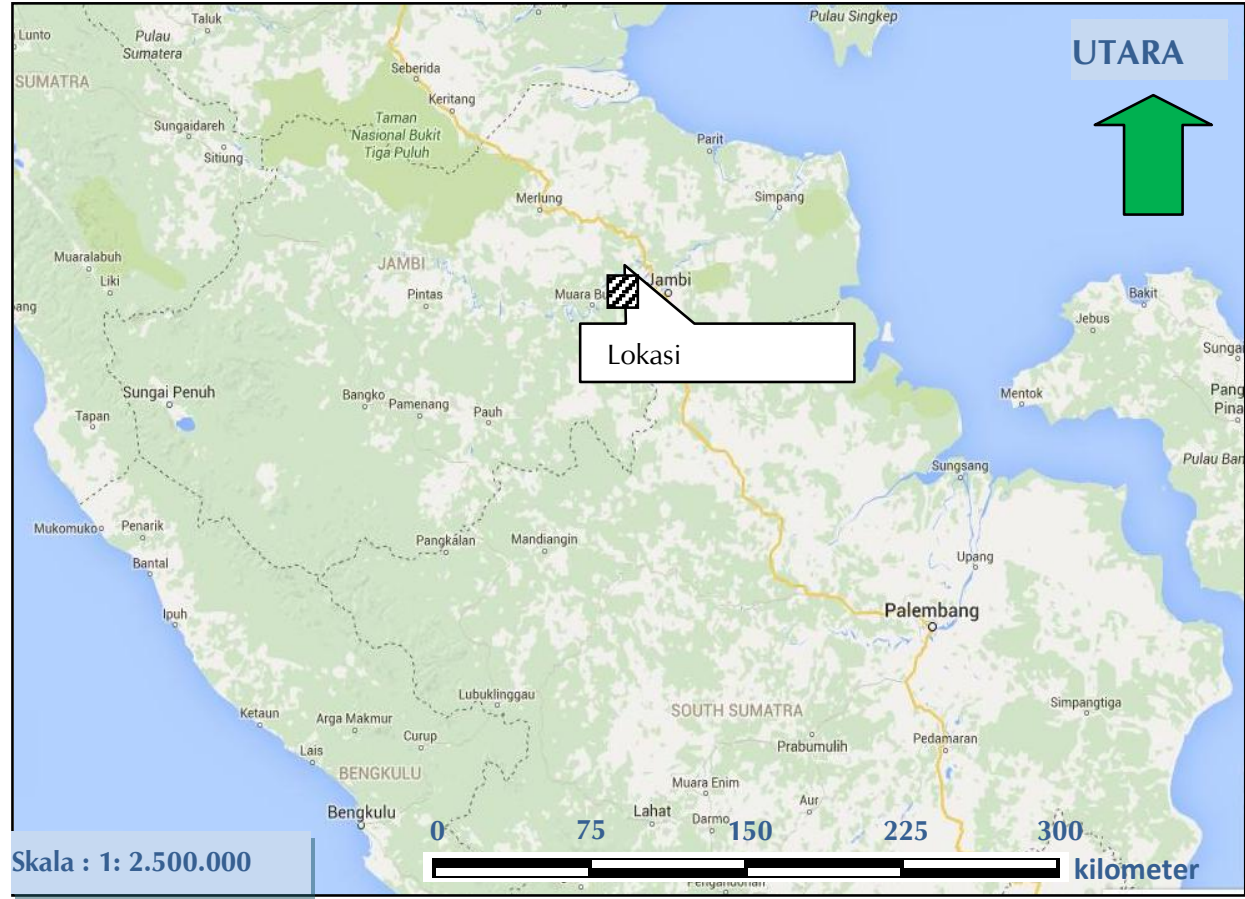

Gambar 1. Letak geografis lokasi penyelidikan

\section{Tahanan Jenis Batuan}

Tahanan jenis beberapa batuan, tanah dan material kebumian ditunjukkan pada Tabel 1 (Rustadi, 2008; Yulianto dan Widodo, 2008; Asmaranto, 2012). Batuan beku dan metamorf biasanya memiliki nilai $\rho$ tinggi. $\rho$ batuan bergantung pada pori, tingkat rekahan dan persentase pori, retakan/kekar yang terisi oleh airtanah. Jenis batuan ini dapat memiliki berbagai nilai $\rho$, dari sekitar $1.000 \Omega \mathrm{m}$ sampai $10^{7} \Omega \mathrm{m}$, tergantung pada keadaannya, apakah lapuk atau segar, basah atau kering. Batuan sedimen biasanya lebih berpori dan memiliki kandungan air lebih tinggi. Oleh karena itu, batuan ini memiliki nilai tanahan jenis lebih rendah dibandingkan dengan batuan beku dan metamorf, yakni antara 10-10.000 $\Omega \mathrm{m}$, dengan nilai rata-rata $<1.000 \Omega \mathrm{m}$.

Tabel 1. Tahanan jenis ( $\rho$ ) beberapa jenis material kebumian

\begin{tabular}{lc}
\hline \multicolumn{1}{c}{ Jenis Batuan } & Kisaran Tahanan Jenis $(\Omega . m)$ \\
\hline Granit & $3.10^{-2}-10^{6}$ \\
Dasit & $2.10^{4}$ (basah) \\
Andesit & $4,5.10^{4}$ (basah) $-1,7.10^{2}$ (kering) \\
Diabas & $20-5.10^{7}$ \\
Basal & $10-1,3.10^{7}$ \\
Tufa & $2.10^{3}\left(\right.$ basah) $-10^{5}$ (kering) \\
Marmer & $10^{2}-2,5.10^{8}$ (kering) \\
Tanah (lapukan batuan) & $10-2.10^{2}$ \\
Lempung & $1-100$ \\
Aluvial dan pasir & $10-800$ \\
Batugamping & $50-10^{7}$ \\
Konglomerat & $2,5-10^{4}$ \\
Batubara (in-situ) & $60-2200$ \\
Air tanah (di batuan) & $10-100$ \\
Air payau (3\%) & $0-15$ \\
Air laut & $0-2$ \\
\hline
\end{tabular}


Material tak terkonsolidasi (tanah dan material hasil sedimentasi) umumnya memiliki nilai $\rho$ lebih rendah dari pada batuan sedimen, sekitar $10 \Omega \mathrm{m}$ sampai $<1.000 \Omega \mathrm{m}$. pbatuan bergantung pada nilai porositas (dengan asumsi semua pori-porinya jenuh terisi airtanah) serta kandungan mineral lempung. $\rho$ batuan yang jenuh airtanah bervariasi dari 10-100 $\Omega \mathrm{m}$, bergantung pada konsentrasi garam terlarut. Air laut mempunyai $\rho$ rendah (rata-rata $<2 \Omega \mathrm{m}$ ).

\section{GEOLOGI}

Wilayah penyelidikan mencakup tiga formasi yaitu, Air Benakat, Muara Enim, Kasai dan endapan aluvial (Tabel 2).

Formasi Air Benakat berumur Miosen Tengah sampai awal Miosen Atas. Arah umum jurus formasi ini barat laut-tenggara dengan kemiringan berkisar $20^{\circ}-40^{\circ}$. Ciri litologi formasi ini adalah di bagian bawah didominasi batulempung abu-abu gelap kebiruan sampai abu-abu gelap kecoklatan, setempat tufaan, lunak dan getas; bagian tengah disusun oleh batupasir halus-sedang, glaukonit, hijau mudaabu-abu kecoklatan mengandung kuarsa, felspar dan fragmen batuan lain; bagian atas disusun oleh perselingan batupasir, batulempung, batulanau dan serpih dengan sisipan tipis pasir kuarsa. Satuan batuan ini terbentuk pada fasa regresi, bersifat endapan laut dangkal. Di daerah penyelidikan pada formasi ini tidak dijumpai batubara.

Formasi Muara Enim diendapkan selaras di atas Formasi Air Benakat dengan tebal 200-800 meter, merupakan formasi pembawa batubara yang berumur Miosen Atas-Pliosen Bawah. Berdasarkan kelompok kandungan lapisan batubara, formasi ini dibagi menjadi empat anggota, yaitu M1, M2, M3 dan M4. Formasi ini diendapkan sebagai kelanjutan dari fasa regresi. Anggota M1 merupakan perulangan batupasir, batulanau, batulempung dengan sisipan batubara. Batupasir berwarna abu-abu sampai abu-abu kecoklatan, berbutir halus hingga sedang, kompak, terpilah baik, dengan fragmen kuarsa dominan. Perselingan batulempung dan batupasir, berwarna abu-abu, terdapat nodul-nodul batugamping, coklat terang, keras. Sementara itu, batulanau berwarna abu-abu, kompak, umumnya berselingan dengan batulempung. Batubara dijumpai dua lapisan dengan ketebalan antara $0,5 \mathrm{~m}$ sampai $1 \mathrm{~m}$.

Tabel 2. Stratigrafi Regional Cekungan Sumatera Selatan

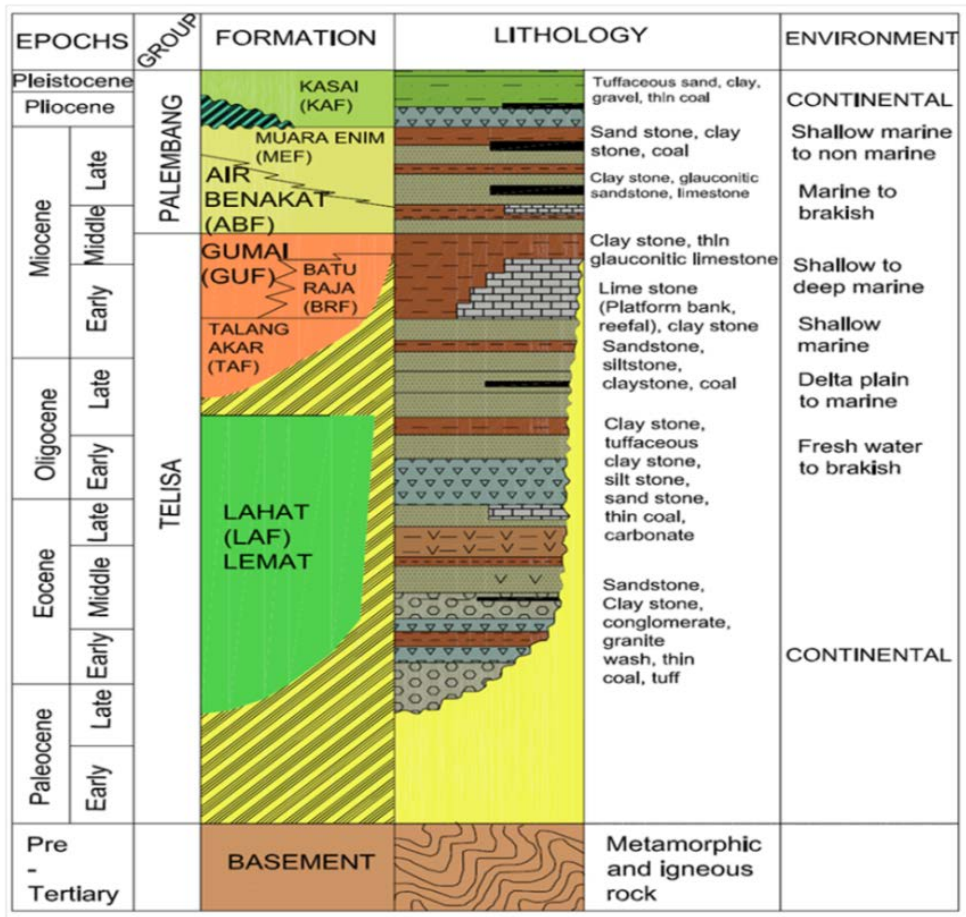

Sumber : De Coster, 1974, hasil modifikasi 
Anggota M2 merupakan satuan batuan yang terdiri atas batulempung, batulempung karbonan, batupasir, batulanau dan batubara. Batulempung umumnya berwarna abu-abu gelap, masif, sering ditemukan struktur sedimen laminasi paralel, jejak tumbuhan serta fragmen batubara. Batulempung karbonan, berwarna abu-abu kecoklatan, umumnya agak lunak dan biasanya bertindak sebagai batuan pengapit batubara. Batupasir berwarna abu-abu terang sampai abu-abu kehijauan, berbutir halus sampai sedang, membulat sedang, terpilah buruk, mudah terurai, fragmen kuarsa dominan. Batulanau berwarna abu-abu kehijauan hingga abu-abu kecoklatan, kompak, umumnya ditemukan struktur sedimen laminasi paralel. Batubara yang ditemukan pada anggota M2 ini berjumlah tiga lapisan dengan tebal antara 0,3 m sampai 6,6 m.

Anggota M3 merupakan satuan batuan yang terdiri atas batupasir, batulanau, batulempung, dan batubara. Batupasir berwarna abu-abu, berbutir halus, terpilah baik, mineral kuarsa dominan. Batulanau, abu-abu terang kehijauan sampai kecoklatan, kompak, struktur sedimen laminasi paralel, mengandung jejak tumbuhan. Batulempung berwarna abu-abu kecoklatan, kompak, masif, banyak dijumpai jejak tumbuhan. Batubara ditemukan dua lapisan tebal 1,0 $\mathrm{m}$ sampai $8,1 \mathrm{~m}$.

Anggota M4 terdiri atas batupasir, batulanau, batulempung, dan batubara. Batupasir berwarna abu-abu terang, berbutir halus, terpilah baik, tufan dan mineral kuarsa banyak dijumpai. Batulanau, abu-abu terang, kompak, mengandung jejak tumbuhan, struktur tumbuhan, struktur sedimen laminasi paralel. Batulempung berwarna abu-abu kecoklatan, lunak, kompak, struktur sedimen laminasi, pararel dan jejak tumbuhan banyak ditemukan. Batubara pada anggota M4 ditemukan dua lapisan dengan ketebalan berkisar antara 1,0 $\mathrm{m}$ sampai 3,7 $\mathrm{m}$.

Formasi Kasai diendapkan di atas Formasi Muara Enim berumur Pliosen, tersusun dari batulempung tufaan biru kehijauan dan biru, batupasir tufaan hijau, batuapung, sedangkan endapan aluvial terdiri atas kerakal, kerikil, batupasir halus-kasar, lepas-lepas.

Secara lokal, kenampakan struktur di wilayah penyelidikan merupakan hasil dari gaya tegasan utama, yaitu gaya kompresif berarah barat laut-timur laut, yang menghasilkan pola struktur lipatan regional antiklinorium dan sinklinorium yang bersumbu barat lauttenggara. Di beberapa tempat akibat tegasan tersebut mengakibatkan terjadinya penyesaran, baik sesar mendatar maupun sesar normal.

\section{Pengukuran Data Lapangan}

Pengukuran data lapangan menggunakan alat SuperSting $^{\text {TM }}$ R8/IP buatan AGI, USA, multi elektroda (56 elektroda) dengan output arus $2.000 \mathrm{~mA}$, kisaran pengukuran $+/-10 \mathrm{~V}$ dan output tegangan 400 Volt DC (Advanced Geosciences, 2005). Sumber tenaga menggunakan dua buah aki basah, masingmasing 12 Volt/120 AH. Kabel untuk bentangan elektroda terdiri atas dua jenis, yaitu jenis dengan spasi elektroda maksimum $6 \mathrm{~m}$ dan $50 \mathrm{~m}$ (panjang maksimum 330 meter dan 2.750 meter).

Pengukuran memakai konfigurasi Wenner dan Schlumberger (Zubaidah dan Kanata, 2008), jarak antar elektroda 6 meter dan 30 meter dengan jumlah elektroda 56, sehingga panjang bentangan 330 meter dan 1.650 meter. Untuk spasi elektroda 6 meter pada konfigurasi Wenner, variasi jarak $M N=6$ 108 meter dan $\mathrm{AB}=18$ - 324 meter, sedangkan pada konfigurasi Schlumberger jarak $M N=6-60$ meter dan $A B=42-330$ meter. Untuk spasi elektroda 30 meter pada konfigurasi Wenner, variasi jarak $M N=30$ 540 meter dan $\mathrm{AB}=90-1.620$ meter, sedangkan pada konfigurasi Schlumberger jarak $M N=30-300$ meter dan $A B=210$ 1.650 meter. Pengalihan dan pengaturan perpindahan fungsi elektroda dari dan ke $M$, $\mathrm{N}$, A dan B (pasangan $\mathrm{MxN}_{\mathrm{x}}$ dan $\mathrm{A}_{\mathrm{y}} \mathrm{By}$ ) secara bergantian, diatur otomatis oleh alat dengan sampling rate 3,2 detik setiap pengukuran. Diperlukan waktu sekitar 2,5 jam untuk setiap pengukuran metode Wenner dan Schlumberger. Sebagian besar waktu dipergunakan untuk pembuatan rintisan, penguraian dan penggulungan kabel serta pemasangan elektroda. Untuk panjang lintasan 1.650 meter, diperlukan sekitar 3-5 hari untuk setiap lintasan, karena kondisi cuaca, medan dan topografi yang cukup sulit. Setiap kali pengukuran menghasilkan rata-rata 450 sampai 490 data setiap konfigurasi. 
Skema susunan multi-elektroda untuk pengukuran adalah seperti pada Gambar 2 .

Pengukuran dilakukan di tujuh lintasan dengan spasi elektroda $6 \mathrm{~m}$ dengan panjang lintasan $330 \mathrm{~m}$ dan di dua lintasan dengan spasi elektroda $30 \mathrm{~m}$ dan panjang lintasan $1.650 \mathrm{~m}$, masing-masing 2 kali pengukuran (Wenner dan Schlumberger). Waktu (tanggal bulan) dilakukannya pengukuran untuk masing-masing lintasan dapat dilihat pada Tabel 3. Notasi "J" dan "K" pada kode lintasan, menunjukkan lintasan pengukuran dalam arah jurus dan kemiringan lapisan batuan. Pekerjaan lapangan pengukuran data geolistrik dapat dilihat pada fofo-foto di Gambar 3. Posisi lintasan-lintasan geolistrik dapat dilihat dalam peta pada Gambar 8.

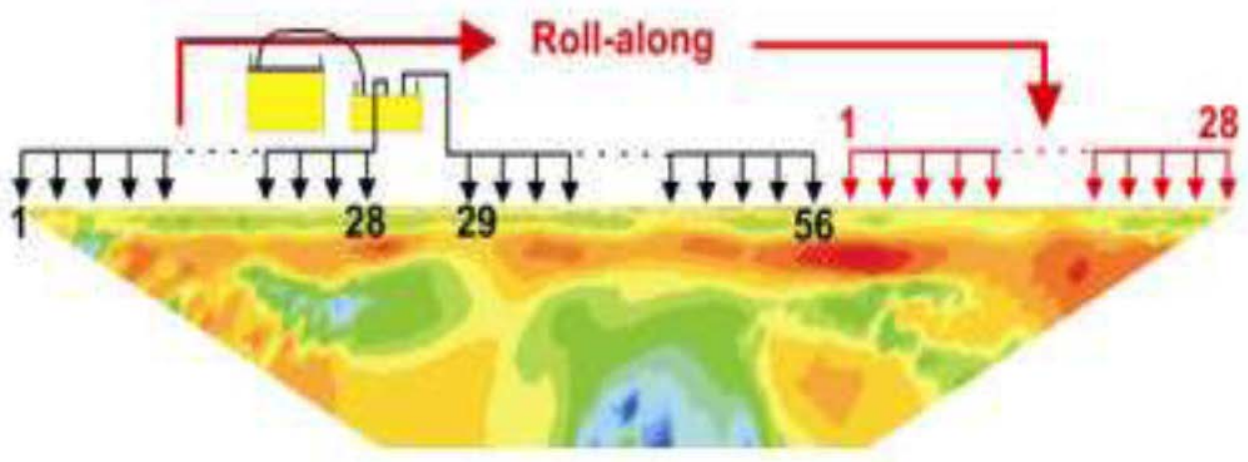

Gambar 2. Skema susunan multi-elektroda
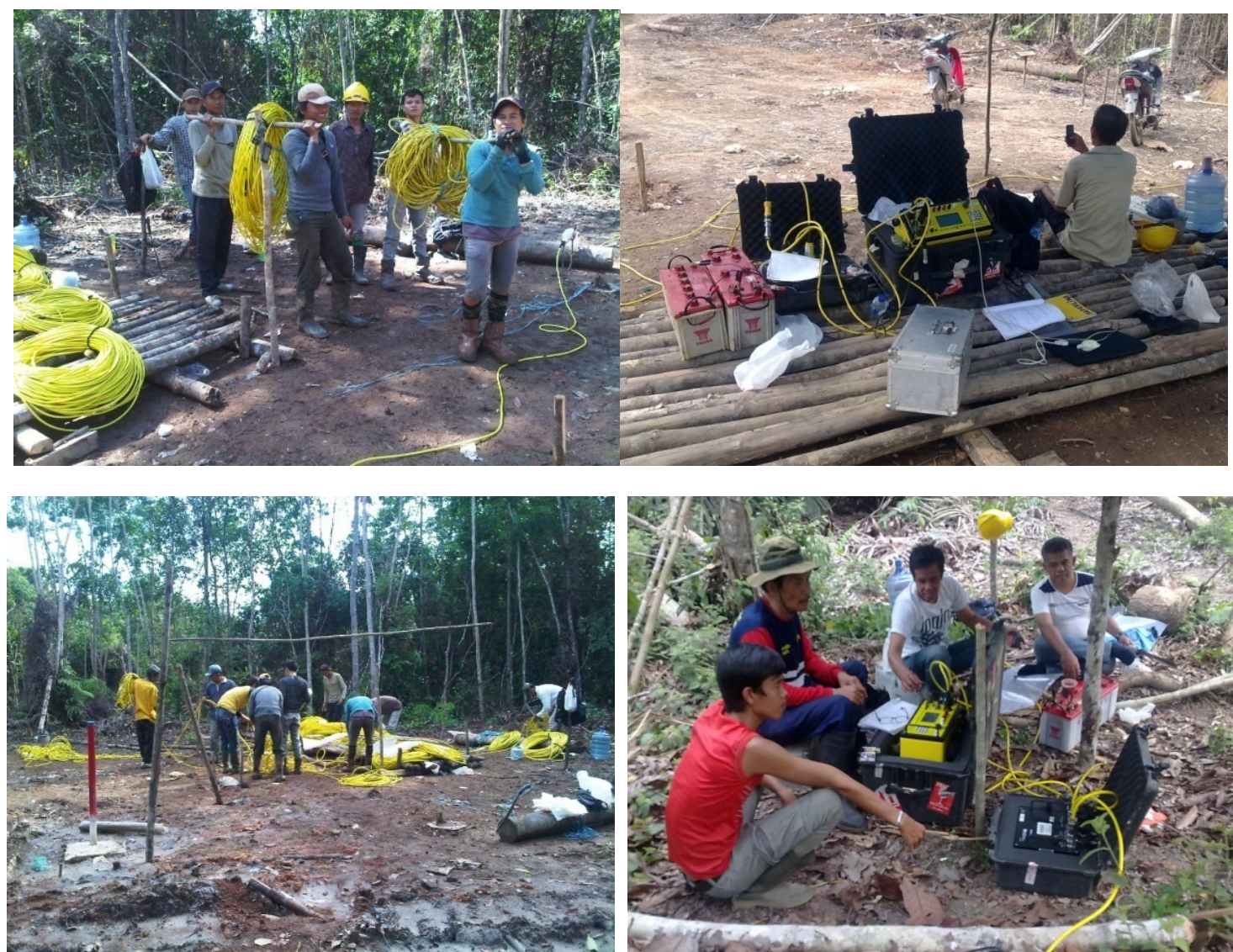

Gambar 3. Kegiatan lapangan pengukuran data geolistrik 
Tabel 3. Data lintasan pengukuran eolistrik

\begin{tabular}{cccccl}
\hline \multirow{2}{*}{$\begin{array}{c}\text { Nomor } \\
\text { Pengukuran }\end{array}$} & $\begin{array}{c}\text { Kode Lintasan } \\
\text { Pengukuran }\end{array}$ & $\begin{array}{c}\text { Tanggal } \\
\text { Pengukuran }\end{array}$ & $\begin{array}{c}\text { Spasi } \\
\text { Elektroda } \\
\text { (meter) }\end{array}$ & $\begin{array}{c}\text { Panjang } \\
\text { Lintasan } \\
\text { (meter) }\end{array}$ & \multicolumn{1}{c}{ Keterangan } \\
\hline 1 & SKY61J & $01-11-2015$ & 6 & 330 & Sejajar strike perlapisan \\
2 & SKY62K & $02-11-2015$ & 6 & 330 & Sejajar dip perlapisan \\
3 & SKY62J & $13-11-2015$ & 6 & 330 & Sejajar strike perlapisan \\
4 & SKY63K & $06-11-2015$ & 6 & 330 & Sejajar dip perlapisan \\
5 & SKY63J & $05-11-2015$ & 6 & 330 & Sejajar strike perlapisan \\
6 & SKY64S & $08-11-2015$ & 6 & 330 & UCG-2B, sejajar strike \\
7 & SKY65K & $09-11-2015$ & 6 & 330 & UCG-1A, sejajar dip \\
8 & SK301J & $26-11-2015$ & 30 & 1650 & UCG-8, sejajar strike \\
9 & SK301K & $02-12-2015$ & 30 & 1650 & UCG-8, sejajar dip \\
\hline
\end{tabular}

Pekerjaan lapangan dimulai dengan penentuan lintasan pengukuran, pembuatan rintisan, pemasangan patok elektroda, pemasangan kabel dan elektroda dan pengukuran data tahanan jenis semu. Data $\rho$ semu hasil pengukuran (measured apparent resistivity) diproses dengan software Earth Imager 2D dan RES2DINV untuk mendapatkan calculated apparent resistivity. Data dengan nilai anomali, yaitu data yang nilainya terlalu besar ataupun terlalu kecil dibandingkan data lainnya (misfit data) dihilangkan setelah dilakukan proses inversi (dengan smooth model inversion). Proses ini dimaksudkan untuk meminimalkan jumlah misfit data antara data pengukuran lapangan dengan data hasil perhitungan pada model rekonstruksi sampai diperoleh nilai RMS error minimal.

Sampai pada tahap ini hasil pemrosesan masih sulit untuk diinterpretasikan, karena range nilai-nilai $\rho$ masih dalam skala yang besar (1-10.000 $\Omega \mathrm{m}$ ). Nilai phasil pemrosesan software ini ditampilkan dalam visualisasi gradasi warna dalam skala logaritma, sehingga $\rho$ yang nilainya jauh berbeda mempunyai warna yang seakan-akan sama dan menempati kisaran skala warna yang sempit. Pada Gambar 4 misalnya, lintasan SKY61J sulit dibedakan antara nilai $2.000 \Omega \mathrm{m}$ dengan $10.000 \Omega \mathrm{m}$ atau antara $50 \Omega \mathrm{m}$ dengan 400 $\Omega \mathrm{m}$, karena sama-sama berwarna merah dan hijau. Margin error (selisih antara nilai model dengan nilai hasil pengukuran) dalam pemrosesan data pada semua lintasan dengan software ini adalah antara 7,9\%-39,7\% sedangkan nilai ketepatan pengukuran pada alat adalah $\pm 1 \%$.

\section{HASIL DAN PEMBAHASAN}

Untuk menghilangkan efek data tahanan jenis tinggi yang berada di permukaan tanah yang sesungguhnya tidak diperlukan maka dilakukan reduksi terhadap data dengan nilai $\rho$ tinggi, sehingga dibuat nilai maksimum untuk spasi 6 meter adalah $1.000 \Omega$ m dan spasi $30 \mathrm{~m}$ adalah $3.000 \Omega \mathrm{m}$ dengan pertimbangan bahwa di lokasi penyelidikan didominasi oleh batuan sedimen dengan kisaran $\rho$ rata-rata $<1.000 \Omega \mathrm{m}$. Dengan distribusi kisaran $\rho$ antara 1-1.000 $\Omega$ m dan 1$3.000 \Omega \mathrm{m}$, maka skala warna menjadi lebih lebar, sehingga pemisahan antara $\rho$ tinggi dan rendah secara visual berdasarkan skala warna bisa dilakukan lebih detil dan mudah. Contoh hasil pemrosesan pada tahap ini ditampilkan pada Gambar 5 dan 6. Setelah dibuat dari nilai maksimum $\rho 10.000 \Omega$ m menjadi 1.000 $\Omega \mathrm{m}$, maka lintasan SKY61J dan SKY301K pada Gambar 5 dan 6 ini lebih mudah dibedakan antara nilai tahanan jenis tinggi dan rendah, demikian juga untuk lintasan-lintasan yang lain.

Pada penampang tegak $\rho$ ini, nilai $\rho$ di setiap titik ditampilkan sebagai warna tertentu, setiap warna mewakili nilai $\rho$ tertentu pula, yang besarnya dapat dibaca di skala. Oleh karena itu, untuk menentukan distribusi $\rho$ bisa dengan menghitung luas masing-masing warna yang dikehendaki. Dengan mengacu besarnya nilai $\rho$ pada Tabel 1 , yaitu bahwa batuan mengandung airtanah dan lapisan lempung mempunyai nilai $\rho$ antara 1-100 $\Omega \mathrm{m}$, maka bisa ditentukan berapa persen luas area yang mempunyai nilai $\rho$ antara $10-100$ $\Omega \mathrm{m}$ dan berapa persen luas area yang 
mempunyai nilai $\rho$ lebih tinggi. Dari perbandingan luas masing-masing warna yang merupakan representasi dari nilai $\rho$ ini bisa diprediksi distribusi kejenuhan batuan pada penampang tegak tersebut (Hadi, 2012; Asmaranto, 2014; Pryambodo, 2014).
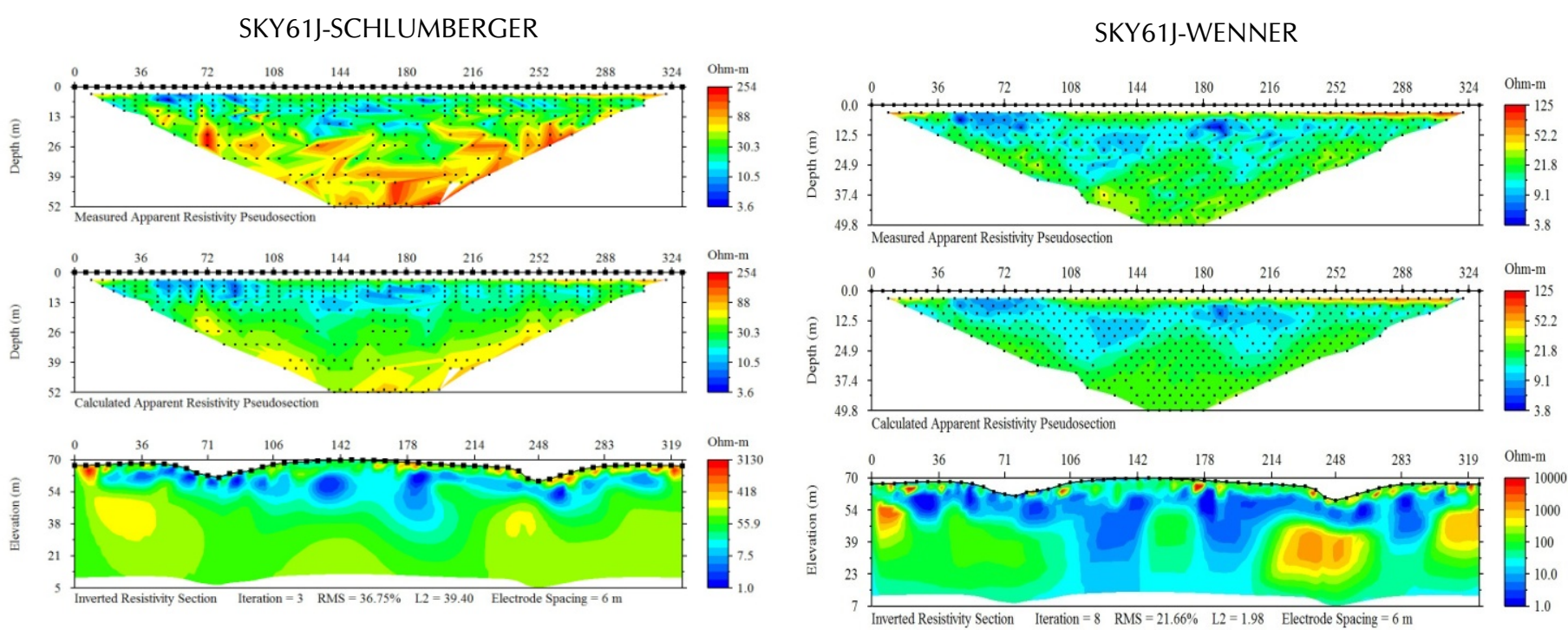

Gambar 4. Hasil pemrosesan awal data geolistrik di lintasan SKY61J
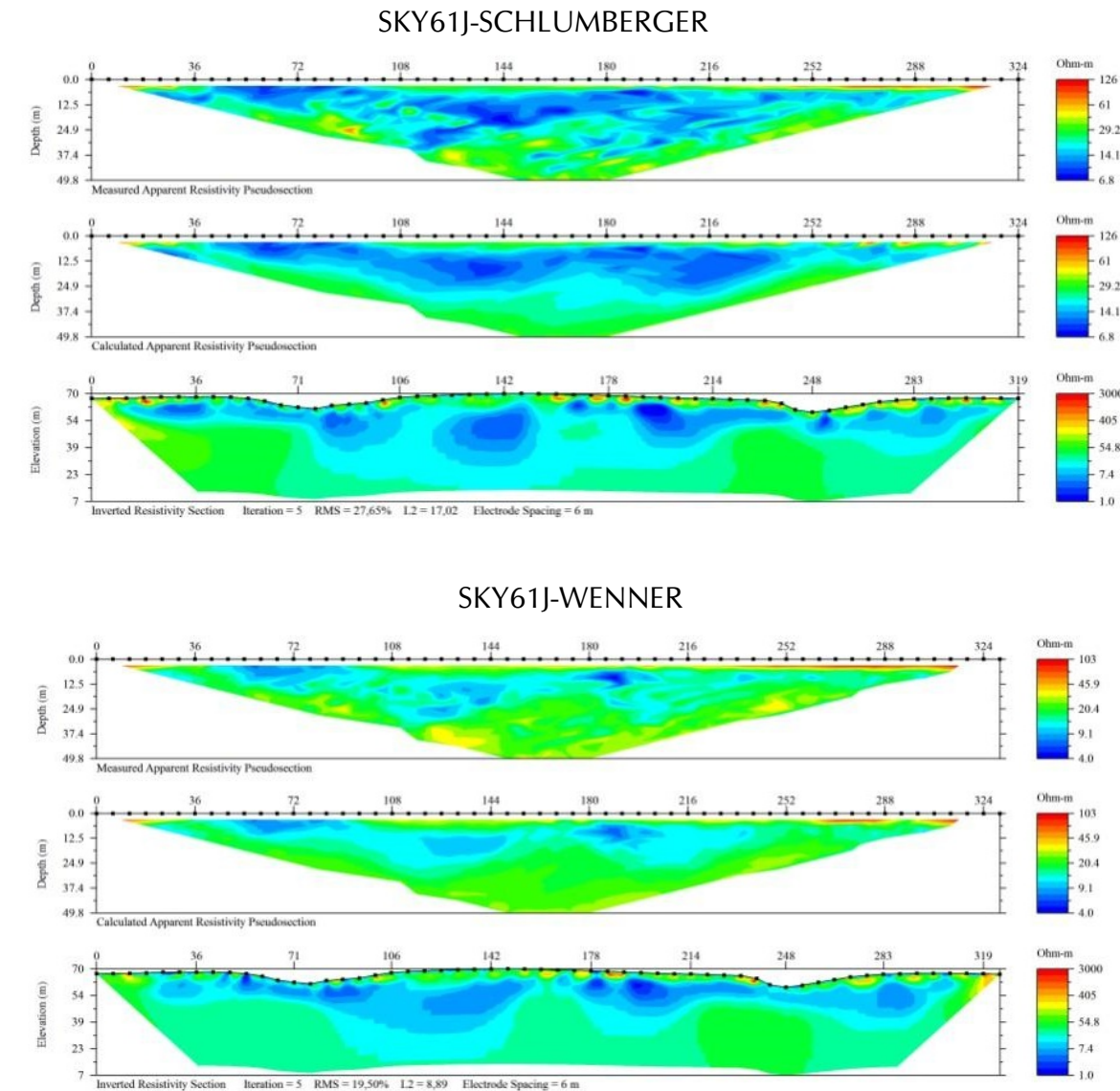

Gambar 5. Hasil pemrosesan akhir data geolistrik spasi elektroda 6 meter 

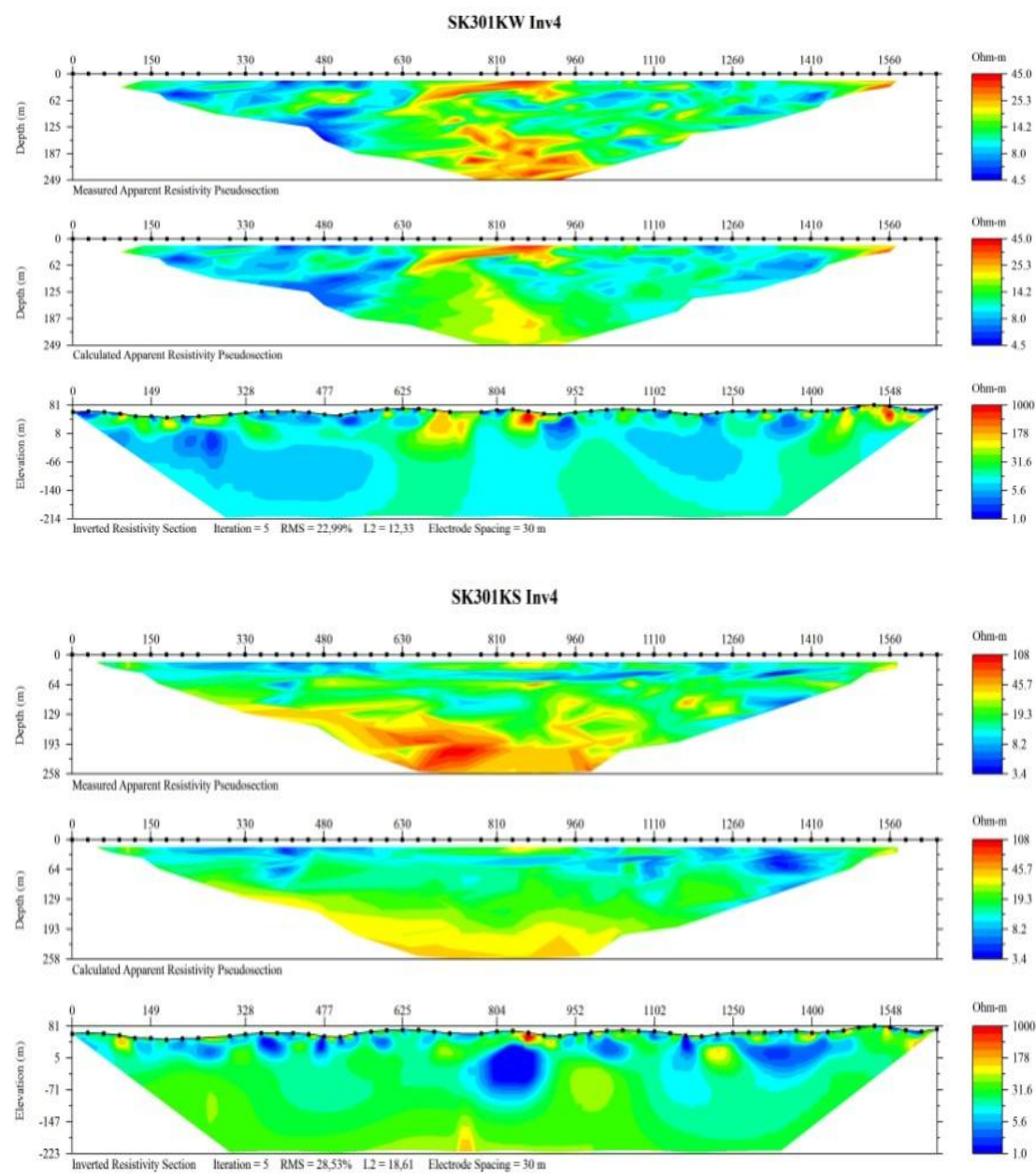

Gambar 6. Hasil pemrosesan akhir data geolistrik spasi elektroda 30 meter

Untuk menghitung luas area digunakan software AutoCAD. Contoh perhitungan luas pada penampang lintasan SK301JW di Gambar 7 (SK301JW berarti spasi elektroda 30 meter, lintasan 1, searah jurus perlapisan batuan, konfigurasi Wenner). Luas area dengan $\rho>100$ $\Omega \mathrm{m} \sim 4.549$ satuan luas, sedangkan luas penampang keseluruhan $\sim 479.681$ satuan luas. Jadi luas area dengan $\rho>100 \Omega m$ dibandingkan dengan luas area penampang keseluruhan $=4.549 / 479.681=0,0095=$ $0,95 \%$, demikian pula untuk penampangpenampang yang lain. Hasil perhitungan perbandingan luas pada masing-masing penampang tegak tercantum dalam Tabel 4 yang dinyatakan dalam persentase luas area dengan $\rho>100 \Omega m$ yang diprediksi sebagai zona tidak jenuh karena $\rho<100$ adalah zona jenuh/airtanah (Purnama dan Sulaswono, 2006; Wardani $d k k$., 2016) dibandingkan dengan luas penampang keseluruhan. Hal ini menunjukkan bahwa rata-rata zona tidak jenuh dalam batuan di wilayah penyelidikan sangat minim, yaitu $<5 \%$. Hal ini berarti pula bahwa mayoritas batuan adalah kemungkinan jenuh airtanah atau terdiri atas lapisan lempung (Hadi, 2012; Asmaranto, 2014; Pryambodo, 2014).

Dari hasil perhitungan luas pada seluruh lintasan di Tabel 4 menunjukkan bahwa mayoritas lintasan didominasi oleh batuan dengan tahanan jenis $<100 \Omega$ m sampai kedalaman 300 meter dengan persentase lebih dari 95\%. Hal ini dapat diinterpretasikan bahwa hampir seluruh lapisan batuan di bawah permukaan di wilayah penelitian terdiri atas batuan yang jenuh airtanah atau terdiri atas batuan lempung (Asmaranto, Soemitro and Anwar, 2012; Hadi, 2012). Hal ini ditunjang juga dengan data bahwa 
berdasarkan beberapa data pengeboran inti di lokasi penyelidikan, banyak dijumpai lapisan batulempung yang cukup tebal. Oleh karena itu, penyelidikan ini sebaiknya dilanjutkan dengan uji pompa untuk mengetahui karakteristik hidrolika batuan di lokasi pengukuran secara kuantitatif (nilai konduk- tivitas hidrolik dan koefisien kandungan), apakah bersifat akuifer atau bukan. Karena diperkirakan bahwa batuan di lokasi pengukuran berpotensi jenuh airtanah, maka perlu diwaspadai dalam pengoperasian UCG nantinya.

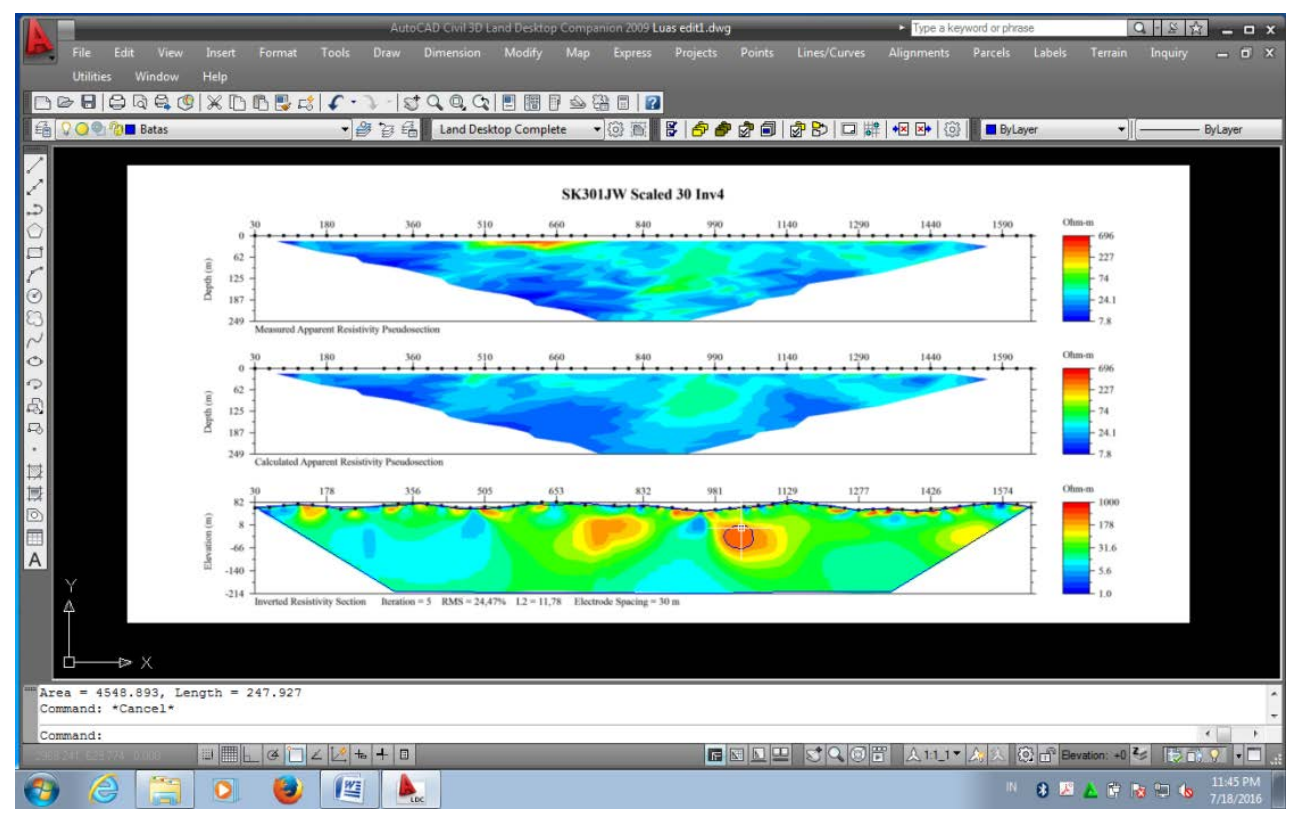

Gambar 7. Perhitungan luas area penampang

Tabel 4. Distribusi Tahanan Jenis ( $\rho$ ) dalam Penampang Tegak

\begin{tabular}{clccccl}
\hline $\begin{array}{c}\text { Nomor } \\
\text { urut } \\
\text { Lintasan }\end{array}$ & $\begin{array}{c}\text { Kode } \\
\text { Lintasan } \\
\text { Pengukuran }\end{array}$ & $\begin{array}{c}\text { Luas } \\
\text { penampang } \\
\text { keseluruhan }\end{array}$ & $\begin{array}{c}\text { Luas } \\
\text { penampang } \\
\text { dengan } \\
\rho<100 \Omega \mathrm{m}\end{array}$ & $\begin{array}{c}\text { Luas } \\
\text { penampang } \\
\text { dengan } \\
\rho>100 \Omega \mathrm{m}\end{array}$ & $\begin{array}{c}\text { Persentase } \\
\text { area } \\
\text { dengan } \\
\rho>100 \Omega \mathrm{m}\end{array}$ & Keterangan \\
\hline 1 & SKY61JW & 480.628 & 480.628 & 0 & 0 & Sejajar jurus perlapisan \\
& SKY61JS & 480.628 & 480.628 & 0 & 0 & Sejajar kemiringan \\
2 & SKY62KW & 484.753 & 483.749 & 1.004 & 0,21 & perlapisan \\
& SKY62KS & 484.753 & 484.177 & 1.576 & 0,33 & Sejajar jurus perlapisan \\
3 & SKY62JW & 466.186 & 444.449 & 21.737 & 4,67 & \\
& SKY62JS & 466.186 & 442.257 & 23.929 & 5,13 & Sejajar kemiringan \\
4 & SKY63KW & 482.453 & 463.115 & 19.338 & 4,01 & perlapisan \\
& SKY63KS & 482.453 & 465.430 & 17.023 & 3,53 & Sejajar jurus perlapisan \\
\multirow{2}{*}{5} & SKY63JW & 481.219 & 476.056 & 5.163 & 1,07 & UCG-2B, sejajar jurus \\
& SKY63JS & 481.219 & 475.904 & 5.315 & 1,10 & perlapisan \\
6 & SKY64JW & 447.368 & 442.750 & 4.618 & 1,03 & UCG-1A, sejajar \\
& SKY64JS & 447.368 & 442.415 & 4.953 & 1,11 & kemiringan perlapisan \\
7 & SKY65KW & 465.733 & 461.497 & 4.236 & 0,91 & UCG-8, sejajar jurus \\
& SKY65KS & 465.733 & 461.691 & 4.042 & 0,87 & perlapisan \\
8 & SK301JW & 479.681 & 475.132 & 4.549 & 0,95 & UCG-8, sejajar \\
& SK301JS & 479.681 & 472.034 & 7.647 & 1,59 & kemiringan perlapisan \\
\hline
\end{tabular}




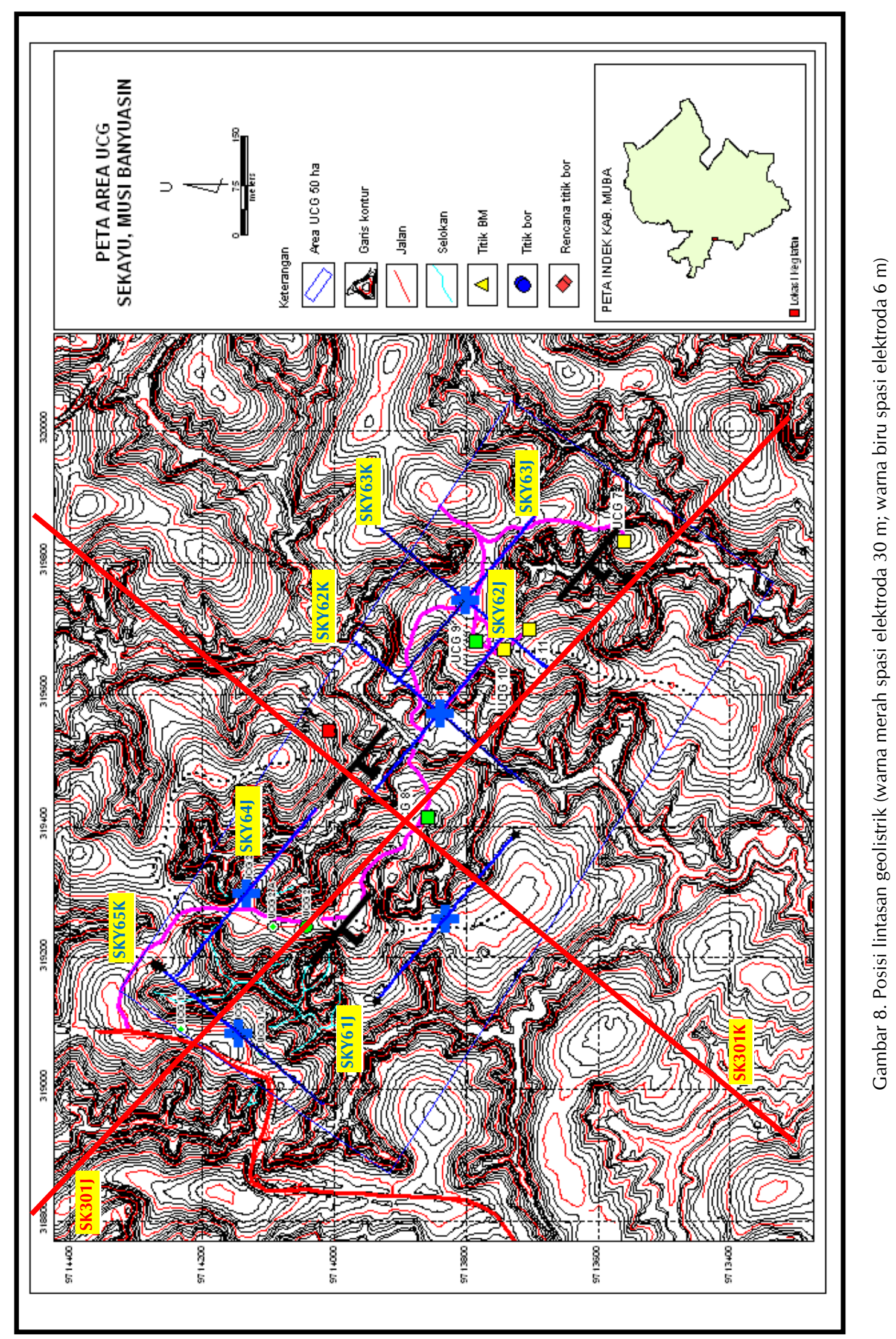




\section{KESIMPULAN DAN SARAN}

Dari pengukuran dengan spasi 6 meter yang menghasilkan deteksi kedalaman sekitar 60 meter yang ditampilkan pada penampang SKY61J, SKY62J, SKY62K, SKY63J, SKY63K, SKY64J dan SKY65K terlihat bahwa seluruh penampang mayoritas terdiri atas batuan dengan $\rho<100 \Omega m$, bahkan di lintasan SKY61J seluruh penampang terdiri atas $\rho<100 \Omega \mathrm{m}$. Hanya di lintasan SKY62J, SKY62K, SKY63J, SKY63K terdapat nilai $\rho>100 \Omega m$, itupun $<5 \%$ dan hanya berada relatif dangkal (kedalaman $<40$ meter).

Dari pengukuran dengan spasi 30 meter yang menghasilkan deteksi kedalaman sekitar 300 meter pada penampang SK301J dan SK301K terlihat bahwa seluruh penampang juga mayoritas terdiri atas batuan dengan $\rho<100$ $\Omega \mathrm{m}$, sampai kedalaman sekitar 300 meter. Hal ini dapat diperkirakan berdasarkan nilai $\rho$ bahwa kondisi batuan di lokasi pengukuran kemungkinan terdiri atas batuan yang jenuh airtanah dan/atau lapisan batulempung, karena nilai $\rho$-nya berada pada kisaran yang sama. Lapisan batubara D di lokasi ini yang rencananya akan digasifikasi, terdapat pada kedalaman sekitar 270 meter, tetapi tidak terdeteksi secara khusus dalam penampang.

Untuk meyakinkan apakah kondisi batuan dengan $\rho<100 \Omega m$, ditimbulkan oleh adanya batuan jenuh airtanah atau karena adanya lapisan batulempung, diperlukan uji pompa agar dapat diketahui karakteristik hidrolika batuan secara kuantitatif (nilai konduktivitas hidrolik dan koefisien kandungan), apakah batuan tersebut bersifat akuifer atau tidak. Namun demikian, setidaknya penyelidikan ini telah memberikan peringatan dini adanya kemungkinan zona jenuh airtanah yang perlu diwaspadai karena akan berpengaruh pada tahap pembakaran dan gasifikasi lapisan batubara.

\section{UCAPAN TERIMA KASIH}

Ucapan terima kasih penulis sampaikan kepada manajemen Tim Litbang UCG Puslitbang tekMIRA dan PT. Astaka Dodol yang telah memfasilitasi kegiatan penyelidikan dengan metode geolistrik ini serta seluruh anggota Tim Penelitian UCG, terutama anggota tim geolistrik yang telah membantu dalam pengambilan data di lapangan.

\section{DAFTAR PUSTAKA}

Advanced Geosciences (2005) The SuperSting ${ }^{T M}$ with Swift ${ }^{T M}$ automatic resistivity and IP system: Instruction Manual. Austin, Texas: Advanced Geosciences, Inc.

Advanced Resources International (2003) Indonesian Coalbed Methane. Advanced Resources International.

Asmaranto, R. (2012) Identifikasi air tanah menggunakan metode resistivity (geolistrik with IP2WIN Software).

Asmaranto, R. (2014) "Identifikasi potensi akuifer menggunakan uji resistivity Ves (vertical electrical sounding) (Studi kasus: Desa Pohijo, Sampung-Ponorogo)," Jurnal Teknik Pengairan, 5(2), pp. 199-206. Available at: http://jurnalpengairan.ub.ac.id/index.php/jtp/a rticle/view/220.

Asmaranto, R., Soemitro, R. A. A. and Anwar, N. (2012) "Penentuan nilai konduktivitas hidrolik tanah tidak jenuh menggunakan uji resistivitas di laboratorium," Jurnal Teknik Pengairan, 3(1), pp. 81-86. Available at: http://jurnalpengairan.ub.ac.id/index.php/jtp/a rticle/view/150.

Bahar, H. (2012) "Metode geolistrik untuk mengetahui potensi airtanah di daerah Beji Kabupaten Pasuruan - Jawa Timur," in Prosiding Seminar Nasional Aplikasi Sains \& Teknologi (SNAST) Periode III. Yogyakarta: Institut Sains \& Teknologi Akprind Yogyakarta, pp. B212-B219.

Bayrak, A. A. (2015) “Underground coal gasification (UCG), Value deep-standed Indonesian coals and convert them to electricity-diesel or LNG," in Focus Group Discussion on Acceleration of Underground Coal Gasification Implementation in Indonesia. Jakarta.

De Coster, G. L. (1974) "The geology of central and South Sumatra basin," in Proceedings Indonesian Petroleum Association. 3rd Annual Convention. Jakarta: Indonesian Petroleum Association, pp. 77-110. Available at:

http://archives.datapages.com/data/ipa/data/0 03/003001/77_ipa0030077.htm. 
Hadi, A. I. (2012) "Interpretasi sebaran airtanah dalam berdasarkan data geolistrik tahanan jenis di Kabupaten Jepara, Jawa Tengah," in Prosiding Semirata BKS PTN-B Bidang MIPA, UNIMED Medan. Universitas Medan, pp. 3848.

Pryambodo, D. G. (2014) "Pendugaan airtanah di pesisir Pulau Solor NTT," Jurnal Segara, 10(2), pp. 147-155.

Pujianto, E. (2014) “Pendugaan zona jenuh airtanah dengan metoda geolistrik di sekitar tambang batubara terbuka di Kalimantan Selatan," Jurnal Teknologi Mineral dan Batubara, 10(3), pp. 113-126.

Purnama, S. and Sulaswono, B. (2006) "Pemanfaatan teknik geolistrik untuk mendeteksi persebaran airtanah asin pada akuifer bebas di Kota Surabaya," Majalah Geografi Indonesia, 20(1), pp. 52-66. doi: 10.22146/mgi.13297.

Pusat Sumber Daya Geologi (2012) Neraca energi fossil tahun 2011. Bandung.

Rustadi (2008) "Analisis lapisan batubara di Padang Ratu Lampung melalui pengukuran geolistrik tahanan jenis," Journal Sains MIPA, 14(2), pp. 114-118. Available at: http://jurnal.fmipa.unila.ac.id/index.php/sains/ article/view/196/pdf.

Santoso, B. (2015) "Programme of UCG development in Indonesia," in Focus Group
Discussion on Acceleration of Underground Coal Gasification Implementation in Indonesi. Jakarta.

Santoso, B., Yunianto, B. and Zulfahmi (2015) "Main points for regulation of underground coal gasification in Indonesia," in Proceedings of tekMIRA Colloquium 2015. Bandung: Puslitbang tekMIRA, pp. 13-18.

Wardani, P. I., Wahyono, Cahyo, S. and Sota, I. (2016) "Pendugaan airtanah dengan metoda geolistrik schlumberger di Desa Takuti, Kab. Banjar, Prop. Kalsel," Jurnal Fisika FLUX, 13(1), pp. 79-88. Available at: http://ppjp.unlam.ac.id/journal/index.php/f/art icle/view/1919/1670.

Yulianto, T. and Widodo, S. (2008) "Identifikasi penyebaran dan ketebalan batubara menggunakan metode geolistrik resistivitas (Studi kasus daerah X Kabupaten Kutai Kertanegara Kalimantan Timur)," Berkala Fisika, 11(2), pp. 59-66. Available at: http://ejournal.undip.ac.id/index.php/berkala_ fisika/article/view/2978/2662.

Zubaidah, T. and Kanata, B. (2008) "Pemodelan fisika aplikasi metode geolistrik konfigurasi schlumberger untuk investigasi keberadaan airtanah," Teknik Elektro, 7(1), pp. 20-24. Available at: https://www.researchgate.net/publication/265 119659_Pemodelan_Fisika_Aplikasi_Metode _Geolistrik_Konfigurasi_Schlumberger_untuk K_Investigasi_Keberaraan__Air_Tanah. 
